\title{
Hidden Resilience in the Life of Adolescents with Involvement in Drug Trafficking
}

\author{
Alex Sandro Gomes Pessoa ${ }^{1, *}$, Renata Maria Coimbra², Sílvia Helena Koller ${ }^{3}$, \& Michael Ungar ${ }^{4}$ \\ ${ }^{1}$ Universidade Federal de São Carlos, São Carlos, SP, Brasil \\ ${ }^{2}$ Universidade Estadual Paulista, São Paulo, SP, Brasil \\ ${ }^{3}$ Universidade Federal do Rio Grande do Sul, Porto Alegre, RS, Brasil \\ ${ }^{4}$ Dalhousie University, Halifax, Canadá
}

\begin{abstract}
This paper identifies hidden resilience processes among adolescents and young adults who have had involvement in drug trafficking. The participants were 551 adolescents and young people, aged 12-20 years $(\mathrm{M}=16.01$; $\mathrm{SD}=1.548)$ from both genders, $55.4 \%$ of whom were boys. They were recruited from three social service institutions located in the state of São Paulo, which offer services for adolescents with and without a history of involvement in drug trafficking. To assess rates of resilience, the Child and Youth Resilience Measure was employed. Contrary to expectations, adolescents with greater involvement in drug trafficking had higher rates of resilience. This paper challenges the hegemonic conceptualization of resilience and proposes that more studies of hidden resilience need to be conducted.
\end{abstract}

KEYWORDS: hidden resilience, adolescents, drug trafficking

\section{Resiliência Oculta na Vida de Adolescentes com Envolvimento no Tráfico de Drogas}

\begin{abstract}
RESUMO - Este artigo analisou os indicadores de resiliência oculta em adolescentes que tiveram envolvimento no tráfico de drogas. Participaram 551 adolescentes e jovens, entre 12-20 anos de idade $(M=16,01 ; D P=1,548)$, de ambos os sexos, sendo 55,4\% meninos. Os participantes são provenientes de instituições de três cidades localizadas no interior de São Paulo que atendem adolescentes com e sem histórico de envolvimento no tráfico de drogas. Foi utilizado o instrumento denominado Child and Youth Resilience Measure para verificação dos indicadores de resiliência nas populações. Paradoxalmente, os adolescentes com maior envolvimento no tráfico apresentaram maiores indicadores de resiliência. Questionam-se modelos explicativos hegemônicos sobre resiliência e sugere-se que novos estudos sobre resiliência oculta sejam conduzidos.
\end{abstract}

PALAVRAS-CHAVE: resiliência oculta, adolescentes, tráfico de drogas

Research on resilience has been focused on the search to understand the psychological mechanisms directly involved in the process of overcoming adversities (Masten, 2014; Rutter, 1987). Although there is currently significant variance in the academic literature regarding the definition of resilience, early studies highlighted the concept as something innate to individuals, characterized by attributes naturally occurring in people during developmental stages (Dell'Aglio, Koller, \& Yunes, 2006; Yunes, 2003; Yunes,
2007). As research has progressed, investigators within this area, especially in the field of psychology, acknowledged that resilience should not be understood as something internal. It is neither a biological marker nor a personality trait. Instead, psychological strategies to overcome risk factors and cope with stressful events are associated with the possibility of accessing resources that promote mental health and allow individuals to confront adverse events (Ungar, Liebenberg, Dudding, Armstrong, \& Vijver, 2013).

\footnotetext{
*E-mail: alexpessoa2@gmail.com
} 
Protective resources may therefore be related to subjective or objective factors that nurture in people possibilities of overcoming situations that bring with them adversity. According to Masten and Garmezy (1985), some factors are fundamental to the resilience process: individual characteristics; familial and ecological cohesion; and emotional and social support. Interpersonal relations, for instance, may be permeated by positive moments and memories which help to push people when fighting through various adversities (Daigneault, Hébert, \& Tourigny, 2007; Libório \& Ungar, 2013). Similarly, the role exerted by an institution may occupy a significant space in someone's life, further fostering resilience processes (Dell'Aglio \& Koller, 2011; Krenkel, More, \& Motta, 2015; Pessoa, Coimbra, Murgo, Breda, \& Baker-Lewton, 2018).

Studies on resilience should, therefore, focus not only on the identification of individual characteristics but should also invest in understanding the contextual and relational factors that promote individual strengths and enable individuals to overcome adversity (Edwards \& Apostolov, 2007). Such a shift may reveal creative strategies little explored by psychologists and social scientists.

In the Brazilian context, research on resilience gives special attention to the lived reality of adolescents and young people in situations of social exclusion. The central argument of these studies is characterized by the search for understanding how various groups, including those with high exposure to intense psychosocial risks, are able to navigate through protective resources and demonstrate high levels of resilience in adverse situations. Internationally, examples of research in the literature on resilience includes studies on adolescents who were victims of sexual violence, who are socioeconomically disadvantaged, lacking in education, and experiencing substance abuse, among many others (Albuquerque, Williams, \& D'Affonseca, 2013; Hebert, Lavoie, \& Blais, 2014; Morais, Raffaelli, \& Koller, 2012; Yunes, Garcia, \& Albuquerque, 2007).

Without question, these are situations with the potential to negatively influence the lives of adolescents and young adults. Even so, research has found that some of these young people continue to demonstrate a positive outlook, maintaining high self-esteem and other indicators of resilience despite experiencing threats to their development. These studies aim to describe resilience in ways that reflect acceptable norms for young people's behavior (Bottrell, 2009; Kaplan, 1999). However, it has become increasingly common to find research reports that associate activities considered anti-social with empowerment and social engagement.

This finding led Ungar (2004) to develop the concept of hidden resilience, translated to Portuguese by Libório and Ungar (2010) as resiliencia oculta. Frequently, adolescents and young people in situations of social exclusion identify coping strategies that include involvement in activities considered illegal or anti-social. Morais, Neiva-Silva and Koller (2010) point to the need for adolescents in situations of social vulnerability (e.g., living on the street) to become authors of their own lives. This can be achieved by overcoming difficulties in non-conventional way in order to access mental health resources.

From a clinical perspective, Ungar (2004) has shown that the first-hand accounts of adolescents challenge the hegemonic logic regarding well-being and positive psychosocial development. Ungar found that the presence of resilience indicators demonstrates a negotiation of protective resources through anti-social activities in resource-challenged contexts. These aspects of resilience are neglected by traditional research, which historically has supported examples of mental health that have been arbitrarily defined by culturally normative indicators of resilience during childhood and adolescence (Pessoa \& Coimbra, 2016).

Based on themes addressed by researchers who investigate resilience theory, as well as the experiences of adolescents involved in drug trafficking and sexual exploitation (Libório, 2005; Pessoa \& Coimbra, 2016), a hypothesis emerged that in contexts demarcated by social exclusion and a lack of opportunities, some adolescents may foster resilience by means of illicit activities (Rafaelli, Koller, \& Morais, 2007; Raffaelli, Koller, Reppold, Kuschick, \& Krum, 2000). Even when knowing the daily risks to which they are exposed, some youth are led to engage in illicit activities because these are the only opportunities available to them (Pessoa, 2015).

In this regard, drug trafficking involving adolescents in Brazil has been identified as a public health problem that especially affects adolescents living in regions with high indicators of social exclusion (Rocha, 2013). According to the National System of Social-Educative Care (SINASE), drug trafficking is the second highest recurring crime in the country. In 2011, 5863 cases that resulted in incarceration were from the involvement of young people in drug trafficking (26.6\% of the total). In 2012 this number rose to $5883(27.0 \%$ of the total). The character of secrecy associated with the illegal trade of drugs in Brazil (and indeed around the world) has created a profitable market that also encompasses children and adolescents (France, Bottrell, $\&$ Armstrong, 2012). The financial benefits coming from drug trafficking may be greater than the salaries obtained in labor activities available for adolescents and young people (Bessa, 2010).

The case of drug trafficking in Brazil illustrates how an anti-social activity can become attractive to adolescents who are unable to break the cycle of inter-generational deprivation and social exclusion that denies young people their rights. Even so, the money obtained by adolescents by means of drug trafficking is an illusion when compared to the fortunes made by drug dealers and organized criminal 
factions (Picanço \& Lopes, 2016). Adolescents are the frontline for those organizations, which are the target of few investigations and are responsible for the social problems which result from drug trafficking.

Policies that have been proposed to fight drug trafficking among youth in Brazil tend to delegitimize the principles of human rights. Policy makers have in the past presented misplaced and regressive strategies to confront the issue, from the creation of "invisible" territories for selling and using narcotics, mass murders of drug traffickers, and lowering the age of criminal responsibility to charging youths with adult sentences. These strategies are all palliative measures which do not focus on the historical dimensions that cause adolescents to adopt a lifestyle of drug trafficking. These measures are, therefore, antiquated, short-term, and based on a neoliberal 'blame-the-victim' ideology (Feffermann, 2006).
With the recognition that there is a lack of opportunities for adolescents living in marginal contexts, and that drug dealers manipulate young people into trafficking, it is necessary to develop studies to better understand the meanings of these activities for the adolescents involved. Most importantly, research is needed to identify which aspects of the drug trade adolescents find attractive. Studies discussing the concept of hidden resilience call on researchers to develop new methodologies that will further our understanding of these interests, activities, and unnamed, contextually specific protective processes.

The objective of this paper is, therefore, to verify the existence of processes of hidden resilience in adolescents with involvement in drug trafficking, as well as to evaluate to what degree participation in those activities is associated with elements of positive psychological outcomes and hidden resilience.

\section{METHOD}

\section{Participants}

Participants were 519 adolescents and young adults, 1220 years of age $(M=16.01 ; S D=1.548)$, with $55.4 \%$ males. Participants were recruited in three midsized cities located in São Paulo state. From the total number of participants, 58 young people were residents in a correctional facility because of a history of involvement in drug trafficking. A comparison group (CG) was formed by selecting 461 participants attending public elementary and high schools, as well as clients of a youth service which offers activities after school.

\section{Instrument}

The Child and Youth Resilience Measure (CYRM) was employed in the fieldwork. This instrument was created from an intercultural research project conducted with 1451 adolescents who lived in 14 communities from 11 different countries (Ungar, Brown \& Liebenberg, 2007; Ungar \& Liebenberg, 2008). The scale was translated by the second author of this article, using the technique of translation and back translation (Borsa, Damásio, \& Bandeira, 2012).

The CYRM is composed of three sections: 1) sociodemographic data (age, gender, marital status, ethnicity, monthly family income, and others); 2) items developed locally by researchers, including variables in line with the objectives of the investigation, and which are culturally and contextually relevant (e.g., drug trafficking involving adolescents and positive perceptions associated with processes of personal strengthening and hidden resilience); and 3) items standardized in the original tool, which are indicators of resilience processes mediated by individual, relational, contextual and cultural aspects of a young person's environment.

Items included within Section 2 were based on recommendations found within the national and international literature on adolescence and drug trafficking (Table 1), on positive perceptions associated with processes of personal strengthening, and processes related to hidden resilience that were identified in previous studies. The respondents used a Likert scale from 1 to 5 ( $1=$ Totally Disagree; $2=$ Disagree; $3=$ More or less; $4=$ Agree; $5=$ Strongly Agree) to indicate to what extent they agree with the statements in the questionnaire, such as, "The sale of drugs may help people to improve their condition of life". Only adolescents who had a history of involvement in drug trafficking filled out this section.

Section 3, also structured using a Likert scale of 1 to 5 , has 28 items related to resilience. The CYRM was chosen due to the sensitivity of its creators to contextual aspects of resilience.

\section{Procedures and Data Analysis}

Application of the instrument was made individually or in small groups of 3 to 5 young people. After analyzing the socio-demographic data, the analysis proceeded to adopt a technique of k-medians clustering for the data in Section 2. Researchers were interested in forming two groups of participants: those who valued drug trafficking and those who did not. Group 1 - did not value trafficking-- $(n=24)$ 
had a mean of $17.792(S D=4.482)$ and Group 2 -valued trafficking-- $(\mathrm{n}=34)$ had a mean of $28.735(S D=4.202)$ in a scale that could range between 9 and 45 points. The higher the score obtained in this section, the more positive that drug trafficking was considered to be by the participants.

From the formation of Group 2 (adolescents who considered drug trafficking to be more positive than negative in their lives), it was possible to insert another criterion in order to identify which participants would be most suitable for building the sample that interested the researchers at that moment, and also allowed for the execution of a qualitative study with the adolescents most engaged with drug trafficking. With data organized in Group 1 (G1) and Group 2(G2), the professionals from the institution (composed of psychologists, social workers, and educators) were consulted. These professionals were asked to select from G2 only the adolescents who expressed positive views to drug trafficking during regular programming. After discussions with the professionals, they decided that 8 adolescents from G2 were more involved with drug trafficking and had also presented positive meanings to this activity (Pessoa, 2015; Pessoa \& Coimbra, 2016). Although these 8 participants were interviewed, only CYRM data will be presented in this paper.

After identifying the individuals, three groups were created for this research and were reorganized as follows: High Valuation of Drug Trafficking (HVDT) includes adolescents with involvement in trafficking and who have high indicators of valuing this activity $(n=8)$; Less Valuation in Drug Trafficking (LVDT) includes adolescents with involvement in trafficking but with smaller indicators of positive valuation $(n=50)$; and Group Comparison (GC) includes adolescents from public schools and social projects without involvement in trafficking $(n=461)$. This division allowed for an analysis on indicators of resilience in the lives of adolescents from the three groups.

\section{Ethical Questions}

The study followed recommendations from the National Health Council regarding directions established by Resolution number 466/2012 (in force at the time), which established ethical parameters in research with human beings. Adolescents received information about the procedures, as well as declared their assent on a formal consent form. Because a number of the youth were under the care of the State and living in the correctional system, the Committee of Ethics in Research from the University of the State of São Paulo (UNESP - Presidente Prudente campus, SP), which evaluated the project, asked that judges from the Court of Childhood and Adolescence from the three districts provide formal agreements before the beginning of the fieldwork. After ethical review of the proposed research had occurred, the mentioned Committee issued a favorable opinion regarding the execution of the research (CAEE 26468714.0.0000.5402).

\section{RESULTS}

To begin, we present the results obtained from descriptive statistical and correlation analysis made with items that were derived from Section 2 of the CYRM. Results showed that HVDT were more homogeneous regarding their valuation of activities linked to trafficking. Next, we describe the comparative data regarding the indicators of resilience processes with all groups that provided answers to section 3 of the CYRM, including adolescents from public schools and social projects (CG).

\section{Drug Trafficking as Expression of Personal Positivity and Hidden Resilience}

Table 1 shows the results in averages and standard deviations for each item of Section 2, as well as the differences found between HVDT and LVDT by discriminant analysis. For items "B" and " $F$ " the differences between groups are not significant $(\mathrm{p}<0.05)$, although in all items HVDT show a higher degree of valuation for trafficking.

Items showing greater averages in HVDT were $\mathrm{C}(M=$ 4.625), $\mathrm{H}(4.571)$ and $\mathrm{D}(M=4.375)$, and the item showing the lowest levels was group E $(M=3.571)$. Items with the largest difference between HVDT and LVDT, according to averages obtained, were $\mathrm{C}(\mathrm{HVT}=4.625$ and $\mathrm{MVT}=2.680)$, $\mathrm{G}(\mathrm{HVT}=4.000$ and $\mathrm{MVT}=2.271)$ and $\mathrm{A}(\mathrm{HVT}=4.125$ and MVT $=2.740$ ).

As shown in Table 2, only item B did not significantly discriminate HVDT and MVDT $(\mathrm{p}<0.05)$. The organization of two groups with this technique allowed for a detailed analysis of the indicators of resilience in groups with larger and smaller indicators of concurrence with elements showing positive valuation to drug trafficking.

\section{Indicator of Resilience in Adolescents with Involvement in Trafficking}

Data from Section 3, which measured resilience processes, allowed for a comparative analysis between the three groups. In Table 3, results obtained with Cronbach's alpha suggest reliability of the instrument, both in values obtained in the general population as well as in an analysis 
applied to the factors that make up the CYRM, including individual, relational, community and cultural factors.

Figure 1 shows the average of responses obtained in Section 3 of the CYRM (ranging from 1 to 5). Although no significant statistical difference was found between groups, HVDT had greater indicators of resilience, followed by CG, and next by LVDT. This means that adolescents with greater involvement in drug trafficking and with more elements of valuation for this activity may, according to the instrument used, show greater resilience.

Figure 2 shows the differences found in groups from the factors within the instrument (individual, relationship, community and cultural). Once again, HVDT had greater indicators in all factors, with the Relationship factor being the one with the greatest difference. However, no statistically significant difference was found between these factors either.

In a $t$ test for comparing the means and Cohen's D for definition of the size of the effect (see Table 4), only the "Relationship" factor had a statistically significant difference $(p<0.05)$ between averages of HVDT and LVDT, meaning that the statistical $d$-value size of the effect obtained by this difference is classified as "Great". When the same comparative analyzes is applied between HVDT versus CG and LVDT versus CG, no statistically significant difference was found.

Table 1. Independence test of groups G1 and G2 based on the discriminant analysis for the items of section 2 of CYRM

\begin{tabular}{|c|c|c|c|c|}
\hline Group & $\mathbf{n}$ & $\mathbf{M}$ & SD & \\
\hline A. Drug sales can help people improve their living conditions* & $\begin{array}{l}\text { G1 } \\
\text { G2 }\end{array}$ & $\begin{array}{c}8 \\
50\end{array}$ & $\begin{array}{l}4.125 \\
2.740\end{array}$ & $\begin{array}{l}1.126 \\
1.337\end{array}$ \\
\hline $\begin{array}{l}\text { B. Some people who sell drugs help other families who do not } \\
\text { have money to buy food or medicine }\end{array}$ & $\begin{array}{l}\text { G1 } \\
\text { G2 }\end{array}$ & $\begin{array}{c}8 \\
50\end{array}$ & $\begin{array}{l}3.875 \\
3.020\end{array}$ & $\begin{array}{l}0.835 \\
1.169\end{array}$ \\
\hline $\begin{array}{l}\text { C. Some people who sell drugs gain respect and admiration } \\
\text { in the place where they live* }\end{array}$ & $\begin{array}{l}\text { G1 } \\
\text { G2 }\end{array}$ & $\begin{array}{c}8 \\
50\end{array}$ & $\begin{array}{l}4.625 \\
2.680\end{array}$ & $\begin{array}{l}0.518 \\
1.096\end{array}$ \\
\hline $\begin{array}{l}\text { D. News on TV, newspapers and magazines show a wrong } \\
\text { image about people who sell drugs * }\end{array}$ & $\begin{array}{l}\text { G1 } \\
\text { G2 }\end{array}$ & $\begin{array}{c}8 \\
50\end{array}$ & $\begin{array}{l}4.375 \\
3.100\end{array}$ & $\begin{array}{l}0.916 \\
1.129\end{array}$ \\
\hline E. Selling drugs should be seen as a worthy way of working* & $\begin{array}{l}\text { G1 } \\
\text { G2 }\end{array}$ & $\begin{array}{c}7 \\
50\end{array}$ & $\begin{array}{l}3.571 \\
2.520\end{array}$ & $\begin{array}{l}1.134 \\
1.129\end{array}$ \\
\hline F. Some people prefer to sell drugs instead of going to school & $\begin{array}{l}\text { G1 } \\
\text { G2 }\end{array}$ & $\begin{array}{c}8 \\
50\end{array}$ & $\begin{array}{l}4.250 \\
3.360\end{array}$ & $\begin{array}{l}1.389 \\
1.241\end{array}$ \\
\hline G. Selling drugs can be more fun than other forms of work* & $\begin{array}{l}\text { G1 } \\
\text { G2 }\end{array}$ & $\begin{array}{c}8 \\
48\end{array}$ & $\begin{array}{l}4.000 \\
2.271\end{array}$ & $\begin{array}{l}1.414 \\
1.005\end{array}$ \\
\hline H. Selling drugs can be a way out of poverty * & $\begin{array}{l}\text { G1 } \\
\text { G2 }\end{array}$ & $\begin{array}{c}7 \\
49\end{array}$ & $\begin{array}{l}4.571 \\
3.367\end{array}$ & $\begin{array}{l}0.787 \\
1.220\end{array}$ \\
\hline
\end{tabular}

Table 2. Equivalence test of HVDT and LVDT averages from the Wilks' Lambda test applied to Section 2 of the CYRM

\begin{tabular}{lccc}
\hline Item & Wilks' Lambda & F & $\boldsymbol{p}$-value \\
\hline A & 0.890 & 6.553 & $0.013^{*}$ \\
B & 0.942 & 3.243 & 0.077 \\
C & 0.672 & 25.848 & $0.000^{*}$ \\
D & 0.823 & 11.425 & $0.001^{*}$ \\
E & 0.909 & 5.332 & $0.025^{*}$ \\
F & 0.867 & 8.114 & $0.006^{*}$ \\
G & 0.771 & 15.747 & $0.000^{*}$ \\
H & 0.892 & 6.423 & $0.014^{*}$ \\
Sum & 0.711 & 21.539 & $0.000^{*}$ \\
\hline
\end{tabular}

Table 3. Means and Cronbach's alpha analysis among the factors present in Section 3 of CYRM

\begin{tabular}{cccccc}
\hline & HVDT & LVDT & CG & Total & $\begin{array}{c}\text { Cronbach's } \\
\text { alpha }\end{array}$ \\
\hline Individual & 4.30 & 4.17 & 4.08 & 4.09 & 0.75 \\
Relationship & 4.33 & 3.90 & 3,99 & 3.98 & 0.81 \\
Community & 3.77 & 3.57 & 3.67 & 3.67 & 0.74 \\
Cultural & 4.10 & 3.82 & 3.89 & 3.89 & 0.68 \\
General & 4.16 & 3.88 & 3.92 & 3.92 & 0.90 \\
\hline
\end{tabular}




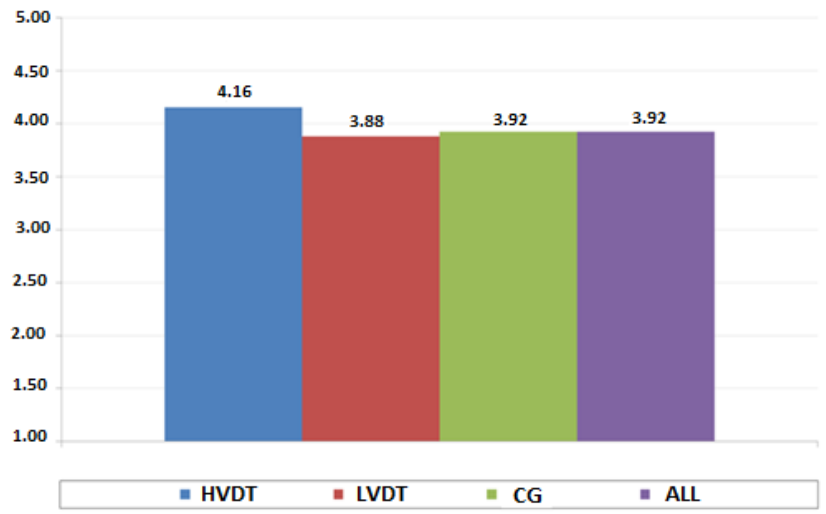

Figure 1. Indicators of resilience from the means obtained in section 3 of the CYRM

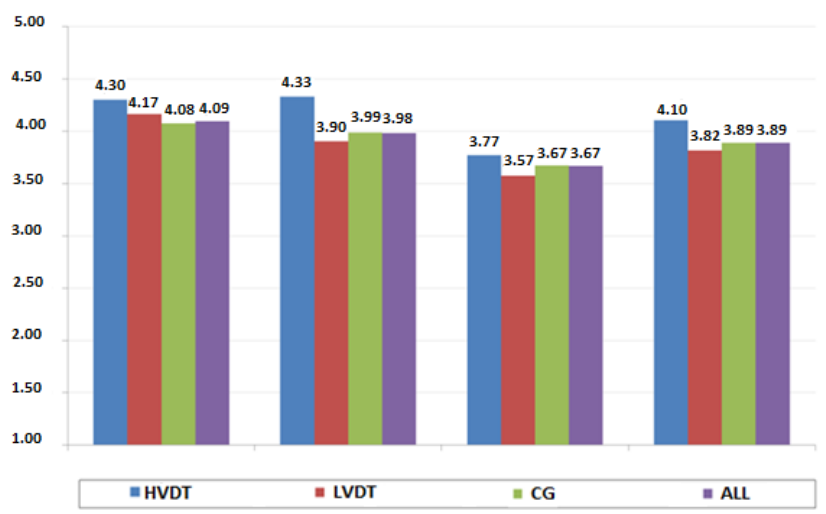

Figure 2. Indicators of resilience presented by factors

Table 4. Comparative analysis of the indicators of resilience between the groups from the test and Cohen's D test

\begin{tabular}{lcccccccc}
\hline & M & SD & M & SD & t-value & p-value & d-value & Effect size \\
\hline & HVDT & LVDT & HVDT/LVDT & & & & & - \\
Individual & 4.30 & 0.62 & 4.14 & 0.55 & 0.76 & $0.45^{*}$ & - & 0.90 \\
Relationship* & 4.33 & 0.42 & 3.82 & 0.59 & 2.34 & 0.02 & - & - \\
Community & 3.77 & 0.93 & 3.54 & 0.77 & 0.77 & $0.45^{*}$ & - & - \\
Cultural & 4.10 & 0.74 & 3.76 & 0.61 & 1.41 & $0.17 *$ & - \\
General & 4.16 & 0.55 & 3.83 & 0.52 & 1.61 & $0.11^{*}$ & - \\
& HVDT & CG & HVDT/CG & & & & - \\
Individual & 4.30 & 0.62 & 4.08 & 0.54 & 1.18 & 0.24 & - \\
Relationship & 4.33 & 0.42 & 3.99 & 0.60 & 1.62 & 0.11 & - \\
Community & 3.77 & 0.93 & 3.67 & 0.62 & 0.43 & 0.66 & - \\
Cultural & 4.10 & 0.74 & 3.89 & 0.64 & 0.93 & 0.35 & - \\
General & 4.16 & 0.55 & 3.92 & 0.50 & 1.31 & 0.19 & - \\
& LVDT & CG & LVDT/CG & & & & - \\
Individual & 4.14 & 0.55 & 4.08 & 0.54 & 0.75 & 0.46 & - \\
Relationship & 3.82 & 0.59 & 3.99 & 0.60 & -1.73 & 0.09 & - \\
Community & 3.54 & 0.77 & 3.67 & 0.62 & -1.35 & 0.18 & - \\
Cultural & 3.76 & 0.61 & 3.89 & 0.64 & -1.24 & 0.22 & - \\
General & 3.83 & 0.52 & 3.92 & 0.50 & -1.14 & 0.25 & - \\
\hline
\end{tabular}

\section{DISCUSSION}

The use of scales in resilience research has been critiqued by some scholars (Reppold, Mayer, Almeida, \& Hutz, 2012), creating a lack of consensus regarding if and how resilience can be measured through the use of scales, as occurs in other psychological studies. Some of the scientific material available for inquiring into possible indicators of resilience in individuals and groups tend to highlight features that are still centered on individuals' characteristics and personality traits (Amar, Utria, Llanos, González, \& Romero, 2014; Cardoso, 2013). Beyond a polarized discussion between disadvantages and potentialities in the use of quantitative instruments in the study of resilience, various scholars have argued that such procedures, including the use of scales, questionnaires or any other technique, must be based on clear epistemic models, reflecting how constructs are understood and evidencing the conceptual bases supporting the proposed research.

Among the various positive attributes that the adolescent participants associated with drug trafficking, one that stood out was the respect that adolescents began to feel in their communities after starting illicit activities. The lack of access to traditional work and therefore popular socioeconomic aspirations, coupled with the feeling of social invisibility that comes with this insufficiency, may cause youth to feel the need to engage in non-conventional activities as a way of obtaining status and power (Feffermann, 2006; Ungar 2004). The possibility of breaking with the condition of poverty was also highlighted by participants as one of the reasons 
leading adolescents to get involved with drug trafficking. In territories marked by indicators of social exclusion and precariousness of resources, illicit activities may represent the only option for overcoming the conditions of scarcity of families (Silva, 2015; Vianna \& Neves, 2011).

Another observation put forward by the participants was an assertion that the media has a mistaken view of people selling drugs. The image broadcasted by the mass media about adolescents in popular culture, especially of young offenders, is permeated by stereotypes and discursive practices that minimize the importance of enforcing the rights of this population (Castro \& Guareschi, 2007). The spectacle and sensationalism broadcast by mass media simply disregards the social context that leads adolescents to become involved in trafficking, and may produce a sense of social injustice from living in socioeconomically disadvantaged settings.

In Pessoa's (2015) study on adolescents involved in drug trafficking, participants recounted inefficiencies with the public services and social policies being offered to the youth population. This lack of resources and services may be a catalyst for young people to disengage from socially normative expectations. Furthermore, the economic precariousness of their families may encourage them to develop alternative strategies for gaining financial resources (Pessoa, Coimbra, Noltemeyer, \& Bottrell, 2017). Due to their inability to access employment and gain social prestige that comes from having a job, there are few opportunities left for the current generation to earn a respectable income and support one's family (Silva, 2015). Added to those elements is the desire for consumption imposed by the media that, in some cases, can only be fulfilled with the involvement of adolescents in activities that put their lives at risk but are highly profitable, such as drug trafficking and sexual exploitation (Davidson \& Taylor, 2007; Shook, Vaughn, \& Salas-Wright, 2013).

Another study by Theron and Malindi (2010) used the same instrument as the study done for this paper, but in a South African context. A comparison of the two shows that all groups in the Brazilian context had greater indicators of resilience compared to the population recruited for the research done in Africa (HVDT= 4.16; $\mathrm{LVDT}=3.88 ; \mathrm{CG}=$ 3.92; South Africa = 3.45). However, in both South Africa as well as in Brazil, the groups that were more exposed to indicators of vulnerability - in the South African case homeless and street-involved-youth and adolescents involved in drug trafficking - demonstrated greater scores in results obtained by means of section 3 of the CYRM (Street-involved adolescents: 3.98; HVDT=4.16).

Rutter (2007) explained that accounting for different types of risk may lead to unexpected results, such as by creating a catalyzing effect in the subject that leads to strengthening processes or wishing to overcome their negative conditions. Through interviews with adolescents involved in drug trafficking, Silva and Graner-Araújo (2011) found several objective characteristics that were considered central in the constitution of juvenile identities engaging in illicit activities, specifically the desire for social recognition, a sense of being related to, and the ability to purchase goods and services.

Therefore, this paper argues that the ideas presented by Ungar (2004) regarding hidden resilience should be kept in mind when studying resilience as it may provide parameters that are not yet taken into consideration during the examination of interventions with vulnerable populations. Top-down social policies may neglect individual historical contexts and overlook pathways to resilience by nonconventional mechanisms that are necessary in resource-poor contexts. The behaviors widely understood as problematic may instead mean empowerment, since data point to drug trafficking being potentially more effective in the lives of adolescents than the services that are offered by the few youth-focused institutions available to them.

Our findings do not indicate, however, an acceptance of drug trafficking as being a possible and healthy means of adolescent development, especially as the daily risks associated with this activity are well known. However, according to Libório and Ungar (2010), findings such as this point to the need for research into which activities and cultural practices may replace the personal identities and cultural meanings that were built or strengthened by means of drug trafficking. What should be prioritized are the individual adolescents who, by being routinely submitted to discriminatory practices and processes of exclusion, are forced to search for alternative strategies promoting social participation. The theory of hidden resilience suggests that those adolescents involved in anti-social behavior would choose more socially acceptable subjective constructions of their identity if their talents were valued and their access to health resources were improved (Ungar, 2004).

The participation of adolescents in activities linked with drug trafficking has its origins in structural questions (Vargas \& Chaves, 2011). However, the findings of this investigation are provocative and bring new questions into the area of resilience research. Although not statistically significant, possibly because o four small sample size, the real differences in scores on the CYRM suggest that greater resilience may be associated with drug trafficking. As this activity is considered in the literature to be a powerful risk indicator for the development of adolescents, our data point to controversies deserving of further analysis by scholars of resilience. 


\section{FINAL CONSIDERATIONS}

Our research reiterates the arguments of hidden resilience and highlights the need for further investigation by researchers in this area. It is worth noting that this study examined the lived reality of adolescents in the corrections system. Therefore, the interventions made by professionals in those institutions may have altered the positive representations that youth had regarding drug trafficking. Hidden resilience is a concept that must be applied to groups that have not received any type of intervention, such as adolescents in conflict with the law, in situations of sexual exploitation, exhibiting behaviors considered to be inadequate in social spaces (such as in schools, streets and social projects), and others.

A further recommendation can be made regarding the selection of instruments and techniques for data collection in studies of this size. Although our data contributes to the discussion of hidden resilience, it is recommended that future analyses make use of more interactive procedures instead of solely relying on conventional methods, such as questionnaires, semi-structured interviews and inventories. Participatory research, the production of images and texts through photovoice, group work, visual methods techniques, and many other qualitative methodologies are all strategies to more effectively communicate with adolescent groups and obtain information still obscure in the comprehension of hidden resilience.

An intriguing finding of this study was the observation that adolescents who had a more intense involvement with drug trafficking demonstrated greater resilience. From the conventional reasoning of studies in the area of resilience, a youth being exposed to indicators of social risk would be associated with vulnerability and not with processes of individual empowerment. This research suggests the need for discovering more examples of this phenomenon to better understand the trajectories traveled by adolescents when building their resilience in precarious situations, even when that resilience is associated with activities considered to be hazardous or anti-social.

\section{REFERENCES}

Albuquerque, P. P., Williams, L. C. A., \& D’Affonseca, S. M. (2013). Efeitos tardios do bullying e transtorno de estresse pós-traumatico: Uma revisão crítica. Psicologia: Teoria $e$ Pesquisa, 29(1), 91-98. http://dx.doi.org/10.1590/S010237722013000100011

Amar, J. J., Utria, L. M., Llanos, R. A., González, M. M., \& Romero, F. A. C. (2014). Construcción de la escala de Factores Personales de Resiliencia (FPR-1) em mujeres víctimas del desplazamiento forzado em Colombia. Universitas Psychologica, 13(3), 853-864. http://dx.doi.org/10.11144/ Javeriana.UPSY13-3.cefp

Bessa, M. A. (2010). Contribuição à discussão sobre a legalização de drogas. Ciência \& Saúde Coletiva, 15(3), 633-636.

Borsa, J. C., Damásio, B. F., \& Bandeira, D. R. (2012). Adaptação e validação de instrumento psicológico entre culturas: Algumas considerações. Paidéia, 22(53), 423-432. http://dx.doi. org/10.1590/S0103-863X2012000300014

Bottrell, D. (2009). Understanding 'Marginal' perspectives: Towards a social theory of resilience. Qualitative Social Work, 8(3), 321339. https://doi.org/10.1177\%2F1473325009337840

Castro, A. L. S., \& Guareschi, P. A. (2007). Adolescentes autores de atos infracionais: Processos de exclusão e formas de subjetivação. Revista Psicologia Política, 7(13), 37-49. Retrieved from http://www.fafich.ufmg.br/rpp/seer/ojs/ viewarticle.php?id=28\&layout=html

Daigneault, D., Hébert, M. H., \& Tourigny, M. (2007). Personal and interpersonal characteristics related to resilient developmental pathways of sexually abused adolescents. Child and Adolescent Psychiatric Clinics of North America, 16, 415-434. https://doi. org/10.1016/j.chc.2006.11.002

Cardoso, T. (2013). Construção e validação de uma escala dos atributos pessoais da resiliência (Master Thesis). Universidade Metodista, São Paulo, SP, Brazil. Retrieved from http://tede. metodista.br/jspui/bitstream/tede/1330/1/TabataCardoso.pdf

Dell'Aglio, D. D., Koller, S. H., \& Yunes, M. A. M. (Eds.). (2006). Resiliencia e psicologia positiva: Interfaces do risco à proteção. São Paulo: Casa do Psicólogo.
Dell'Aglio, D. D., \& Koller, S. H. (Eds.). (2011). Adolescência e juventude: Vulnerabilidade e contextos de proteção. São Paulo: Casa do Psicólogo.

Davidson, J., \& Taylor, J. S. (2007). Infância, turismo sexual e violência: Retórica e realidade. In M. L. P. Leal, M. F. P. L. Leal, R. M. C. \& Libório (Eds.), Tráfico de pessoas e Violência Sexual (pp. 119-136). Brasília: Universidade de Brasília.

Edwards, A., \& Apostolov, A. (2007). A cultural-historical interpretation of resilience: Implications for practice. Critical Social Studies, 1, 70-82. Retrieved from https://tidsskrift.dk/ outlines/article/view/2087

Feffermann, M. (2006). Vidas arriscadas: Um estudo sobre jovens inscritos no tráfico de drogas. Petrópolis - Rio de Janeiro: Editora Vozes.

France, A., Bottrell, D., \& Armstrong, D. (2012). A political ecology of youth and crime. Basingstoke: Palgrave Macmillan.

Hebert, M., Lavoie, F., \& Blais, M. (2014). Post-traumatic stress disorder/PTSD in adolescent victims of sexual abuse: Resilience and social support as protection factors. Ciencia \& Saúde Coletiva, 19(3), 685-695. http://dx.doi. org/10.1590/1413-81232014193.15972013

Kaplan, H. (1999). Toward an understanding of resilience: A critical review of definitions and models. In M. Glantz \& J. Johnson (Eds.), Resilience and development: Positive life adaptations (pp. 17-83). New York: Kluwer Academic/Plenum Publishers.

Krenkel, S., More, C. L. O. O., \& Motta, C. C. L. (2015). The significant social networks of women who have resided in shelters. Paidéia, 25(60), 125-133. http://dx.doi. org/10.1590/1982-43272560201515

Libório, R. M. C. (2005). Adolescentes em situação de prostituição: Uma análise sobre a exploração sexual na sociedade contemporânea. Psicologia: Reflexão e Crítica, 18(3), 413420. http://dx.doi.org/10.1590/S0102-79722005000300016

Libório, R. M. C., Castro, B. M., \& Coelho, A. E. (2006). Desafios metodológicos para a pesquisa em resiliência: Conceitos e reflexões críticas. In D. D.Dell'Aglio, S. H., D. D. Koller, \& M. A. M. Yunes (Eds.), Resiliência e psicologia positiva: Interfaces do risco à proteção (pp. 89-115). São Paulo: Casa do Psicólogo. 
Libório, R. M. C., \& Ungar, M. (2010). Resiliência oculta: A construção social do conceito e suas implicações para práticas profissionais junto a adolescentes em situação de risco. Psicologia Reflexão e Crítica, 23(3), 476-484. http://dx.doi. org/10.1590/S0102-79722010000300008

Libório, R. M. C., \& Ungar, M. (2013). Resilience as protagonism: Interpersonal relationships, cultural practices, and personal agency among working adolescents in Brazil. Journal of Youth Studies, 17(5), 682-696. https://doi.org/10.1080/1367 6261.2013 .834313

Masten, A. (2014). Ordinary magic: Resilience in development. New York: The Guilford Press.

Masten, A. S. \& Garmezy, N. (1985). Risk, vulnerability and protective factors in developmental psychopathology. In B. B. Lahey \& A. E. Kazdin (Eds.), Advances in clinical child psychology (pp.1-52). New York: Plenum Press.

Morais, N. A., Neiva-Silva, L., \& Koller, S. H. (2010). Crianças e adolescentes em situação de rua: história, caracterização e modos de vida. In N. A. Morais, L. Neiva-Silva, \& S. H. Koller. (Eds.), Endereço Desconhecido: crianças e adolescentes em situação de rua (pp. 35-62). São Paulo: Casa do Psicólogo.

Morais, N. A., Raffaelli, M., \&Koller, S. H. (2012). Adolescentes em situação de vulnerabilidade social e o continuum riscoproteção. Avances en Psicologia Latinoamericana, 30(1), 118-136. Retrieved from http://www.scielo.org.co/scielo. php?script=sci_arttext\&pid=S1794-47242012000100010\&ln $\mathrm{g}=\mathrm{en} \& \mathrm{nrm}=\mathrm{iso} \& \mathrm{t} \operatorname{lng}=\mathrm{pt}$

Pessoa, A. S. G. (2015). Trajetórias negligenciadas: Processos de resiliencia em adolescentes com histórico de envolvimento no tráfico de drogas (Doctoral Dissertation). Universidade Estadual Paulista, Presidente Prudente, SP, Brazil. Retrieved from https://repositorio.unesp.br/handle/11449/135963

Pessoa, A. S. G., \& Coimbra, R. M. (2016). Desafiando noções hegemônicas sobre resiliência e indisciplina no contexto escolar. Polêm!ca, 16(2), 59-70. Retrieved from https:// www.e-publicacoes.uerj.br/index.php/polemica/article/ view $/ 22902 / 16384$

Pessoa, A. S. G., \& Coimbra, R. M. (2016). O traficante não vai à escola: Processos de escolarização de adolescentes com envolvimento no tráfico de drogas. Revista Educação em Questão, 54(42), 190-117. https://doi.org/10.21680/19811802.2016v54n42ID10958

Pessoa, A. S. G., Coimbra, R. M., Noltemeyer, A., \& Bottrell, D. (2017). The applicability of hidden resilience in the lives of adolescents involved in drug trafficking. In D. D. Dell'Aglio \& S. H. Koller (Eds.), Vulnerable Children and Youth in Brazil: Innovative Approaches from the Psychology of Social Development (pp. 247-260). New York: Springer International Publishing.

Pessoa, A. S. G., Coimbra, R. M., Murgo, C. S., Breda, A. D. V., \& Baker-Lewton, A. (2018). Resilience processes of Brazilian young people: Overcoming adversity through an arts program. Pesquisas e Práticas Psicossociais, 13(3), 1-17. Retrieved from http://www.seer.ufsj.edu.br/index.php/revista ppp/article/ view/3100/1987

Picanço, F., \& Lopes, N. (2016). O tráfico de drogas em formas: Notas de pesquisa sobre o Rio de Janeiro. Análise Social, 51(218), 96-105. Retrieved from http://www.scielo.mec.pt/scielo. php?script $=$ sci arttext\&pid=S0003-25732016000100004\&ln $\mathrm{g}=\mathrm{pt} \& \mathrm{nrm}=\mathrm{iso} \& \mathrm{t} \operatorname{lng}=\mathrm{pt}$

Raffaelli, M., Koller, S. H., Reppold, C. T., Kuschick, M. B., \& Krum, F. M. B. (2000). Gender differences in Brazilian street youth's family circumstances and experiences on the street. Child Abuse \& Neglect, 24(11), 1431-1441. https://doi. org/10.1016/S0145-2134(00)00202-7

Rafaelli, M., Koller. S. H., \& Morais, N. A. (2007). Assessing the development of Brazilian street youth. Vulnerable Children and Youth Studies, 2(2), 154-164. https://doi. org/10.1080/17450120701403128
Reppold, C. T., Mayer, J. C., Almeida, L. S., \& Hutz, C. S. (2012). Avaliação da resiliência: Controvérsia em torno do uso das escalas. Psicologia: Reflexão e Crítica, 25(2), 248-255. http:// dx.doi.org/10.1590/S0102-79722012000200006

Rocha, A. P. (2013). Proibicionismo e a criminalização de adolescentes pobres por tráfico de drogas. Serviço Social e Sociedade, 115, 561-580. http://dx.doi.org/10.1590/S010166282013000300009

Rutter, M. (1987). Psychosocial resilience and protective mechanisms. American Journal of Orthopsychiatry, 57(3), 316-331. http://psycnet.apa.org/doi/10.1111/j.1939-0025.1987. tb03541.x

Rutter, M. (2007). Resilience, competence and coping. Child Abuse and Neglect,31, 205-209. http://psycnet.apa.org/doi/10.1016/j. chiabu.2007.02.001

Shook, J. J., Vaughn, M. G., \& Salas-Wright, C. P. (2013). Exploring the variation in drug selling among adolescents in the United States. Journal of Criminal Justice, 41(6), 365-374. https:// doi.org/10.1016/j.jcrimjus.2013.07.008

Silva, N. P., Graner-Araújo, R. C. (2011). O adolescente, tráfico de drogas e função paterna. Revista Psicologia Política, 11(21), 141-158. Retrieved from http://pepsic.bvsalud.org/scielo. php? script $=$ sci_arttext\&pid=S1519-549X2011000100011

Silva, T. R. (2015). "Pratas, 'Lacoste', Grana e Novinhas": Um estudo sobre a construção social da adolescência através do ato infracional (Master Thesis). Universidade Estadual Paulista, Franca, São Paulo, SP, Brazil. Retrieved from https:// repositorio.unesp.br/handle/11449/138560

Theron, L. C., \& Malindi, M. J. (2010). Resilient street youth: A qualitative South African study. Journal of Youth Studies, 13(6), 717-736. https://doi.org/10.1080/13676261003801796

Ungar, M. (2004). Nurturing hidden resilience in troubled youth. Toronto: University of Toronto Press.

Ungar, M., Brown, M., Liebenberg, L., Othaman, R., Kwong, W. M., Armstrong, M., \& Gilgun, J. (2007). Unique pathways to resilience across cultures. Adolescence, 42(166), 287-310.

Ungar, M., \& Liebenberg, L. (2008). The child and youth resilience measure CYRM - User manual. International Resilience Project: Dalhousie University, Canada.

Ungar, M. (2011). The social ecology of resilience: Addressing contextual and cultural ambiguity of a nascent construct. American Journal of Orthopsychiatry, 81(1), 1-17. http:// psycnet.apa.org/doi/10.1111/j.1939-0025.2010.01067.x

Ungar, M., Liebenberg, L., Dudding, P., Armstrong, M., \& Vijver, F. J, R. V. (2013). Patterns of service use, individual and contextual risk factors, and resilience among adolescents using multiple psychosocial services. Child Abuse \& Neglect, 37, 150-159. https://doi.org/10.1016/j.chiabu.2012.05.007

Vargas, A. C., \& Chaves, X. C. (2011). El rostro de laviolencia social y estructural: La delincuencia y la pobreza como expresiones distintas de una vulnerabilidad común. Revista Ciencias Sociales, 133(34), 113-124. Retrieved from https://revistas. ucr.ac.cr/index.php/sociales/article/view/3863

Vianna. P. C., \& Neves, C. E. A. B. (2011). Dispositivos de repressão e varejo do tráfico de drogas: Reflexões acerca do racismo de estado. Estudos de Psicologia, 16(1), 31-38. Retrieved from http://www.scielo.br/pdf/epsic/v16n1/a05v16n1.pdf

Yunes, M. A. M. (2003). Psicologia positiva e resiliência: O foco no indivíduo e na família. Psicologia em Estudo, 8,75-84. http:// dx.doi.org/10.1590/S1413-73722003000300010

Yunes, M. A. M., Garcia, N. M., \& Albuquerque, B. M. (2007). Monoparentalidade, pobreza e resiliência: Entre as crenças dos profissionais e as possibilidades da convivência familiar. Psicologia Reflexão e Crítica, 20(3), 444-453. http://dx.doi. org/10.1590/S0102-79722007000300012

Submetido: $17 / 04 / 2017$

Aceito: 09/08/2017 